\title{
Direct Organogenesis from Rhizome Explants in Marsilea quadrifolia L.: A Threatened Fern Species
}

\author{
Mahipal S. Shekhawat and M. Manokari \\ Biotechnology Laboratory, Department of Plant Science, MGGAC, Mahe, Pondicherry 673 311, India \\ Correspondence should be addressed to Mahipal S. Shekhawat; smahipal3@gmail.com
}

Received 17 August 2015; Revised 2 November 2015; Accepted 12 November 2015

Academic Editor: Elisa Rubino

Copyright (C) 2015 M. S. Shekhawat and M. Manokari. This is an open access article distributed under the Creative Commons Attribution License, which permits unrestricted use, distribution, and reproduction in any medium, provided the original work is properly cited.

\begin{abstract}
An efficient micropropagation protocol has been developed for Marsilea quadrifolia L. through direct organogenesis. The mature rhizomes were used as explants and successfully sterilized using $0.1 \% \mathrm{HgCl}_{2}$ for the establishment of cultures. The multiple shoots were differentiated from the explants on Murashige and Skoog (MS) medium augmented with 6-benzylaminopurin (BAP). Full strength MS medium was reported to be effective for the induction of sporophytes from the rhizomes after four weeks of inoculation. Maximum response (96\%) with average of 6.2 shoots ( $2.72 \mathrm{~cm}$ length) was achieved on full strength of MS medium augmented with $0.5 \mathrm{mg} / \mathrm{L}$ BAP in culture initiation experiments. The cultures were further proliferated in clusters $(79.0 \pm 0.37$ shoots per explant) with stunted growth on half strength MS medium supplemented with $0.25 \mathrm{mg} / \mathrm{L}$ BAP after four weeks. These stunted shoots were elongated $(5.30 \mathrm{~cm}$ long) on half MS medium devoid of growth hormones. Root induction and proliferation $(3.0-4.0 \mathrm{~cm}$ long) were observed after 4th subculture of sporophytes on hormone-free half strength MS medium. The rooted plantlets were hardened in the fern house for $4-5$ weeks and transferred to the field with $92 \%$ survival rate. There were no observable differences in between in vivo grown and in vitro propagated plantlets in the field.
\end{abstract}

\section{Introduction}

The pteridophytes are fragile and vulnerable to anthropogenic disturbances and climate changes due to their microclimatic dependence and having a strong affinity on high moisture for sexual reproduction [1]. Marsilea quadrifolia L. (commonly known as water clover, four-leaf clover, or water shamrock) is an aquatic, perennial, and heterosporous fern that belongs to the family Marsileaceae (water clover family) and native to Europe and Asia [2]. It is widespread naturally in central and southern Europe, Caucasia, western Siberia, Afghanistan, southwest India, China, and Japan [3].

The plant body of M. quadrifolia is sporophytic with well branched slender creeping rhizome which is capable of indefinite growth. There are four leaflets of equal size at the tip of each petiole, hence popularly known as fourleaf clovers. The aerial or land leaves exhibit circadian and phototropic movements [4], which have trichomes on adaxial and abaxial surfaces. The leaves show circinate venation when they are young and arise alternately in two rows from the upper surface of the creeping rhizome [5].

M. quadrifolia is chosen for ecotoxicogenomic studies because it is sensitive to aquatic environmental toxicant exposure [6]. It is a high bioaccumulator of heavy metals with maximum bioconcentration factor for cadmium and chromium and could be used for phytosequestration of these metals from contaminated sites [7]. Marsilea was studied exhaustively for its valuable biochemical properties [8-10]. The fern has potential antibacterial, antiinflammatory, diuretic, depurative, febrifuge, refrigerant, antiepileptic, antioxidant, and cytotoxic activities [11-13].

M. quadrifolia is facing major threats due to the climate aridisation, limited distribution of the species, drainage and drying up of the wetlands, redirection of the river beds, overgrowth of marshes, and water pollution [14]. This fern is classified as threatened species and enlisted in the IUCN Red Data Book $[15,16]$. Due to the increasing human activities, all Marsilea species in Europe are considered as 
rare, vulnerable, endangered, at extinction, or extinct in the wild [17]. As per the assessment of World Conservation Monitoring Centre [18], M. quadrifolia is threatened in 21 European countries, vulnerable in eastern Palaearctic region (ecozone), and known to be extinct in Germany, Poland, and Switzerland [19]. The National Biodiversity Act stressed on the conservation needs to protect $M$. quadrifolia in its natural habitats [20]. The fern is also ranked as endangered plant in eastern India [21].

Biotechnological approaches can be used in preservation of genetic material and explored for the reintroduction of the species in nature $[22,23]$. In vitro culture of endangered and rare fern species at mass scale can be exploited as an alternative tool for ex situ conservation. Nephrolepis exaltata bostoniensis was the first fern in which the in vitro propagation protocol was developed for commercial exploitation $[24,25]$. Sporocarps and spores were used as explanting materials in the previous attempts on micropropagation of M. quadrifolia $[26,27]$ which failed to respond under in vitro culture experiments [28]. This is an attempt to develop an efficient micropropagation protocol of aquatic fern $M$. quadrifolia using rhizomes as explants.

\section{Materials and Methods}

2.1. Plant Material and Explants Selection. The plant $M$. quadrifolia was collected from southeast India (swampy area near Villupuram, Pondicherry State) in the months of AprilNovember 2013 and successfully grown in fern house. The rhizomatous nodal explants (stolons) of about $1-2 \mathrm{~cm}$ in length were harvested and brought to the laboratory in order to initiate the cultures in vitro.

2.2. Surface Sterilization of Explants. Since the stolons were used as explants, certain procedures followed to reduce the contamination in cultures: (1) Rhizomatous explants were rinsed with sterile running tap water for $15 \mathrm{~min}$, (2) explants were rinsed with sterile double distilled water and centrifuged at $100 \mathrm{rpm}$ for $5 \mathrm{~min}$, (3) the explants were treated with $0.1 \%$ Bavistin (a systemic fungicide, BASF India Ltd. India) for $15 \mathrm{~min}$, and then (4) surface sterilization was carried out with $0.1 \% \mathrm{HgCl}_{2}$ for $4-5 \mathrm{~min}$ which is followed by washing with sterile distilled water for 5 times under laminar air flow cabinet.

2.3. Culture Medium and Inoculation. Murashige and Skoog (MS) medium [29] was used for the establishment of cultures. The sterilized explants were inoculated aseptically on the half and full strength MS basal medium supplemented with additives $(50 \mathrm{mg} / \mathrm{L}$ ascorbic acid, $25 \mathrm{mg} / \mathrm{L}$ each of citric acid, L-arginine, and adenine sulphate). The medium was augmented with 6-benzylaminopurine (BAP) and 6-furfuryl amino purine (Kinetin) in different concentrations ranging from 0.0 to $3.0 \mathrm{mg} / \mathrm{L}$ to induce shoots from the explants. The amendment of carbon source in the medium was $1.5 \%$ to $3 \%$ of sucrose as per MS salt concentrations, and the gel strength was maintained with the help of $0.8 \%$ agar-agar. The $\mathrm{pH}$ of medium was adjusted to $5.8 \pm 0.02$ with help of $0.1 \mathrm{~N} \mathrm{NaOH} / \mathrm{KOH}$ or $\mathrm{HCl}$. The culture tubes (vessels) were finally incubated at $25 \pm 2^{\circ} \mathrm{C}$ temperature under cool white fluorescent light (Philips, India) with $16 \mathrm{~h}$ artificial photoperiod $\left(40 \mu \mathrm{mol} \mathrm{m} \mathrm{m}^{-2} \mathrm{~s}^{-1}\right.$ Spectral Flux Photon Density, SFPD) at 55-60\% relative humidity $(\mathrm{RH})$.

2.4. Aseptic Culture Proliferation. MS basal medium supplemented with different concentrations of cytokinins (BAP and Kin) with varying concentrations (ranging from 0.0 to $1.0 \mathrm{mg} / \mathrm{L}$ ) was used for multiplication of cultures of $M$. quadrifolia. The culture medium was changed as per the morphogenic response of the cultures using different concentrations of basal salts fortified with different ranges $(0.0$ to $1.0 \mathrm{mg} / \mathrm{L})$ of growth hormones. The cultures were transferred to the fresh medium after 4-5-week intervals and the number and lengths of shoots and roots from rhizomatous sporophyte were evaluated after every 4 weeks of subculture.

2.5. Hardening and Acclimatization of Plantlets. In vitro raised plantlets were rooted simultaneously with culture proliferation stage on same medium combination. Hardening aimed at the introduction of micropropagated plantlets of M. quadrifolia into the greenhouse and finally to the field. The rooted sporophytes were separated from culture medium carefully and washed with distilled water to remove the remains of medium and transferred to sterile soilrite (in paper cups) moistened with one-fourth MS salts solution. The setup was maintained in the fern house for 10 days to ensure high humidity and open shade (diffused light) for hardening. After a week, the plants were shifted to nursery polybags containing garden soil and clay $(1: 1)$ to maintain aquatic environment. Finally the hardened plantlets were transferred to the aquatic, shade field.

2.6. Statistical Analysis. The values presented in each table are means of triplicates with ten replicates each. The results were presented as mean \pm standard deviation (SD) of triplicates. The resulting data were analyzed by analysis of variance with Duncan's multiple range tests where the level of significance was $p<0.05$ using SPSS software (version 16.0).

\section{Results and Discussion}

3.1. Establishment of Cultures. M. quadrifolia cultures were established on MS medium augmented with cytokinins in present study. Cytokinins regulate a considerable number of different developmental and physiological processes in aerial and subterranean organs, like cell divisions in the shoot and root meristems and chloroplast differentiation [30]. These also promote axillary buds proliferation by antagonizing the activity of auxins [31]. The effect of strength of MS medium and the different concentration of plant growth regulators were tested for multiplication and rooting of the shoots. Full strength MS medium was reported to be effective for the induction of fronds from the rhizome explants after four weeks of inoculation. Brownish green meristematic areas developed within two weeks around the notch (nodal part) of rhizome on full strength MS medium supplemented with 
TABLE 1: Effect of different concentrations of cytokinins (BAP and Kin) on induction of shoots from rhizome explants of M. quadrifolia.

\begin{tabular}{lccc}
\hline $\begin{array}{l}\text { Conc. of } \\
\text { cytokinins } \\
(\mathrm{mg} / \mathrm{L})\end{array}$ & $\begin{array}{c}\text { Response } \\
(\%)\end{array}$ & $\begin{array}{c}\text { Number of shoots } \\
(\text { Mean } \pm \text { SD })\end{array}$ & $\begin{array}{c}\text { Shoot length }(\mathrm{cm}) \\
(\text { Mean } \pm \text { SD })\end{array}$ \\
\hline Control $(0.0)$ & 0.00 & $0.0 \pm 0.00^{\mathrm{a}}$ & $0.00 \pm 0.00^{\mathrm{a}}$ \\
BAP & 96 & $6.2 \pm 1.39^{\mathrm{h}}$ & $2.72 \pm 0.40^{\mathrm{f}}$ \\
0.5 & 69 & $3.7 \pm 0.51^{\mathrm{f}}$ & $1.60 \pm 1.25^{\mathrm{g}}$ \\
1.0 & 73 & $4.8 \pm 1.04^{\mathrm{g}}$ & $1.33 \pm 0.18^{\mathrm{e}}$ \\
1.5 & 61 & $3.0 \pm 0.73^{\mathrm{de}}$ & $1.10 \pm 0.12^{\mathrm{b}}$ \\
2.0 & 48 & $4.8 \pm 1.04^{\mathrm{g}}$ & $1.33 \pm 0.18^{\mathrm{e}}$ \\
2.5 & 22 & $2.5 \pm 0.30^{\mathrm{cd}}$ & $0.44 \pm 0.31^{\mathrm{c}}$ \\
3.0 & & & \\
Kin & 57 & $3.3 \pm 0.26^{\mathrm{ef}}$ & $1.31 \pm 0.22^{\mathrm{e}}$ \\
0.5 & 49 & $3.0 \pm 0.14^{\mathrm{de}}$ & $1.08 \pm 0.16^{\mathrm{d}}$ \\
1.0 & 42 & $2.8 \pm 0.40^{\mathrm{de}}$ & $0.85 \pm 0.38^{\mathrm{f}}$ \\
1.5 & 40 & $2.6 \pm 0.39^{\mathrm{d}}$ & $0.93 \pm 0.45^{\mathrm{h}}$ \\
2.0 & 35 & $2.0 \pm 0.81^{\mathrm{c}}$ & $0.49 \pm 0.10^{\mathrm{d}}$ \\
2.5 & 19 & $1.2 \pm 0.22^{\mathrm{b}}$ & $0.32 \pm 0.28^{\mathrm{c}}$ \\
3.0 & &
\end{tabular}

Note: mean separation was analyzed by ANOVA using SPSS software (var. 16.0) and the values represented in corresponding column followed by same letters are not significantly different according to DMRT at $P<0.05$.

$0.5 \mathrm{mg} / \mathrm{L}$ BAP. The maximum response in culture initiation was achieved in presence of low concentrations of BAP $(0.5 \mathrm{mg} / \mathrm{L})$, and $96 \%$ of explants responded well with average of 6.2 shoots with $2.72 \mathrm{~cm}$ length on this combination (Figure 1(a), Table 1). Delayed response of the explants with less number of shoots was observed on half strength MS medium on same hormone concentrations. The shoots were induced after eight weeks of inoculation of explants on the medium. The response of explants with Kin was reported poor as compared to the BAP, and only $57 \%$ explants responded on full strength MS medium supplemented with Kin with 3.3 shoots per explant. The number of shoots was reported stagnant on MS medium supplemented with Kin $(0.5 \mathrm{mg} / \mathrm{L})$, even after four months of incubation.

Generally, ferns micropropagated using spores in most of the studies like Salvinia natans [32], Dryopteris affinis [33], Equisetum arvense [34], Marsilea minuta [35], and Pteris tripartita [36], but the shoots were induced from the nodal part of the rhizomes in present study. It has been reported that the supplementation of abscisic acid in the medium induced shoots, roots, and elongation of petioles of M. quadrifolia [37, 38], whereas the supplementation of auxins has no ameliorative effects on the regenerative response in this plant species [28]. The shoots were proliferated from the mother explants even in absence of abscisic acid and auxins in present study. Rolli et al. [27, 39] also studied the effect of plant hormones on in vitro propagation of $M$. quadrifolia using rhizomes as explants but less number of shoots was induced per explant.
TABLE 2: Effect of growth hormones (BAP and Kin) on multiplication of sporophytes on agar gelled MS medium.

\begin{tabular}{lccc}
\hline $\begin{array}{l}\text { Conc. of BAP } \\
(\mathrm{mg} / \mathrm{L})\end{array}$ & $\begin{array}{c}\text { Conc. of } \\
\text { Kin }(\mathrm{mg} / \mathrm{L})\end{array}$ & $\begin{array}{c}\text { Number of shoots } \\
(\text { Mean } \pm \mathrm{SD})\end{array}$ & $\begin{array}{c}\text { Shoot length }(\mathrm{cm}) \\
(\text { Mean } \pm \text { SD })\end{array}$ \\
\hline 0.00 & 0.00 & $79.0 \pm 0.37^{\mathrm{k}}$ & $5.30 \pm 0.51^{\mathrm{g}}$ \\
0.10 & - & $54.3 \pm 0.46^{\mathrm{fg}}$ & $4.13 \pm 0.30^{\mathrm{e}}$ \\
0.25 & - & $50.9 \pm 0.23^{\mathrm{de}}$ & $4.08 \pm 0.38^{\mathrm{e}}$ \\
0.50 & - & $43.5 \pm 0.51^{\mathrm{c}}$ & $3.20 \pm 0.29^{\mathrm{b}}$ \\
1.00 & - & $40.1 \pm 0.26^{\mathrm{b}}$ & $3.06 \pm 0.57^{\mathrm{b}}$ \\
- & 0.10 & $55.0 \pm 0.71^{\mathrm{g}}$ & $3.74 \pm 0.20^{\mathrm{cd}}$ \\
- & 0.25 & $49.5 \pm 0.37^{\mathrm{d}}$ & $3.51 \pm 0.35^{\mathrm{c}}$ \\
- & 0.50 & $44.2 \pm 0.29^{\mathrm{c}}$ & $3.00 \pm 0.62^{\mathrm{ab}}$ \\
- & 1.00 & $36.6 \pm 0.18^{\mathrm{a}}$ & $2.79 \pm 0.48^{\mathrm{a}}$ \\
0.10 & 0.10 & $68.2 \pm 0.49^{\mathrm{j}}$ & $4.78 \pm 0.42^{\mathrm{f}}$ \\
0.25 & 0.25 & $61.9 \pm 0.35^{\mathrm{i}}$ & $4.22 \pm 0.15^{\mathrm{e}}$ \\
0.50 & 0.50 & $57.3 \pm 0.26^{\mathrm{h}}$ & $3.80 \pm 0.30^{\mathrm{d}}$ \\
1.00 & 1.00 & $52.8 \pm 0.40^{\mathrm{ef}}$ & $3.53 \pm 0.41^{\mathrm{c}}$ \\
\hline
\end{tabular}

Note: mean separation was analyzed by ANOVA using SPSS software (var. 16.0) and the values represented in corresponding column followed by same letters are not significantly different according to DMRT at $P<0.05$.

3.2. Multiplication of Shoots In Vitro. The enhancement of shoots multiplication rate on various concentrations of cytokinins on culture medium was tested. The fresh shoots with mother explants were subcultured to the fresh medium after four weeks of incubation. Cultures were proliferated in clusters on half strength MS medium augmented with additives and $0.25 \mathrm{mg} / \mathrm{L} \mathrm{BAP}$ with stunted growth (Figure 1(b)). Highest mean number of juvenile shoots $(79.0 \pm 0.37$ shoots per explant) was regenerated on this concentration (Table 2). The further growth and elongation of shoots with large number of identical individuals from small parts of inoculums was achieved on half strength MS medium without any growth hormone in present study (Figure 1(c)).

The leaflets with long petiole arise solitarily from the nodes on the rhizomes. The response of the cultures under in vitro conditions was very slow, but frequent subculturing on fresh medium was found the only feasible option to multiply this plant species. It was observed that the shoots with mother explants failed to respond better if they were directly transferred to the hormone-free medium. Therefore, the cultures were first stabilized on $0.25 \mathrm{mg} / \mathrm{L}$ BAP and later transferred to the hormone-free medium. Higher concentrations of cytokinins (both BAP and Kin) showed stunted growth of sporophytic shoots and decreased rate of shoots multiplication. The elongated shoots $(5.30 \mathrm{~cm}$ long) with good roots $(3.0-4.0 \mathrm{~cm}$ length) were developed on MS medium without any growth hormones. In contrast to the present results the effects of cytokinins were found inhibitory on multiplication of cultures of $M$. quadrifolia by Rolli et al. [39]. Spore germination and conversion of gametophytic stage (haploid) into a sporophytic stage (diploid) could be exempted through micropropagation technique in $M$. quadrifolia. M. quadrifolia cultures were also established on 


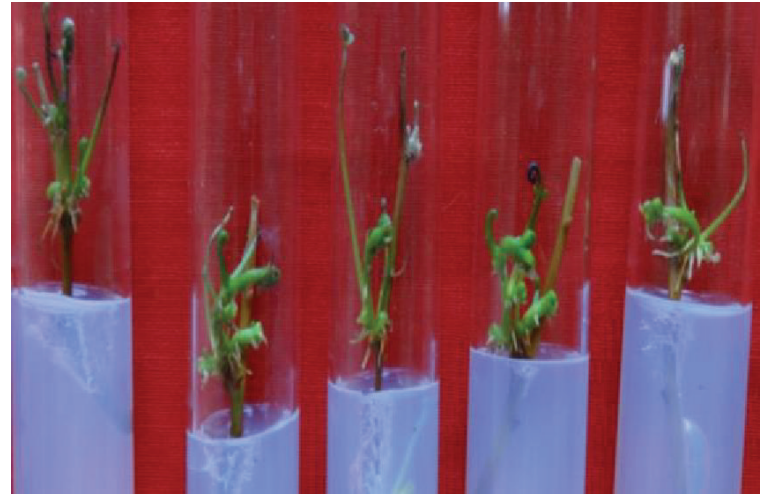

(a)

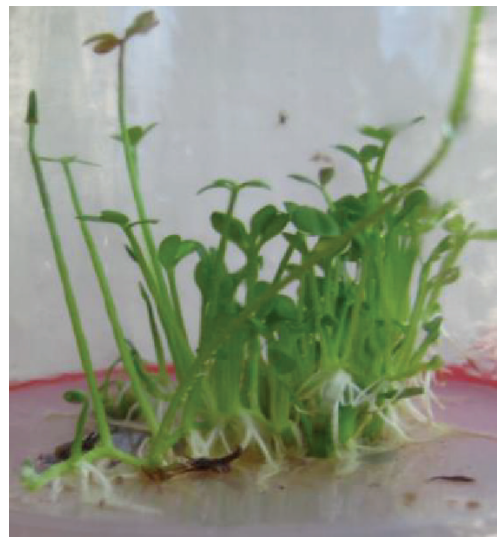

(c)

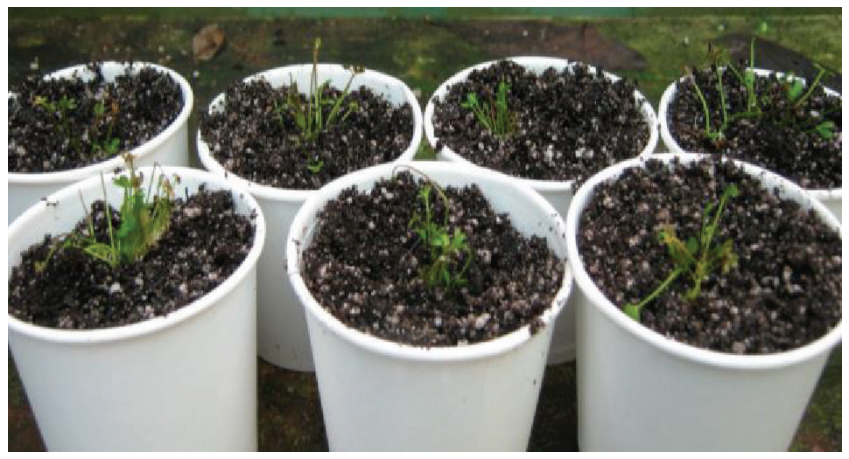

(f)

(d)

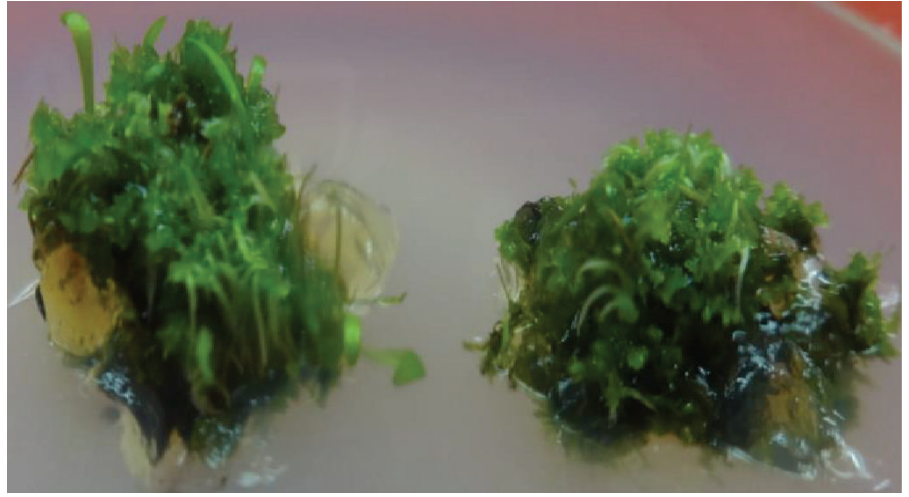

(b)
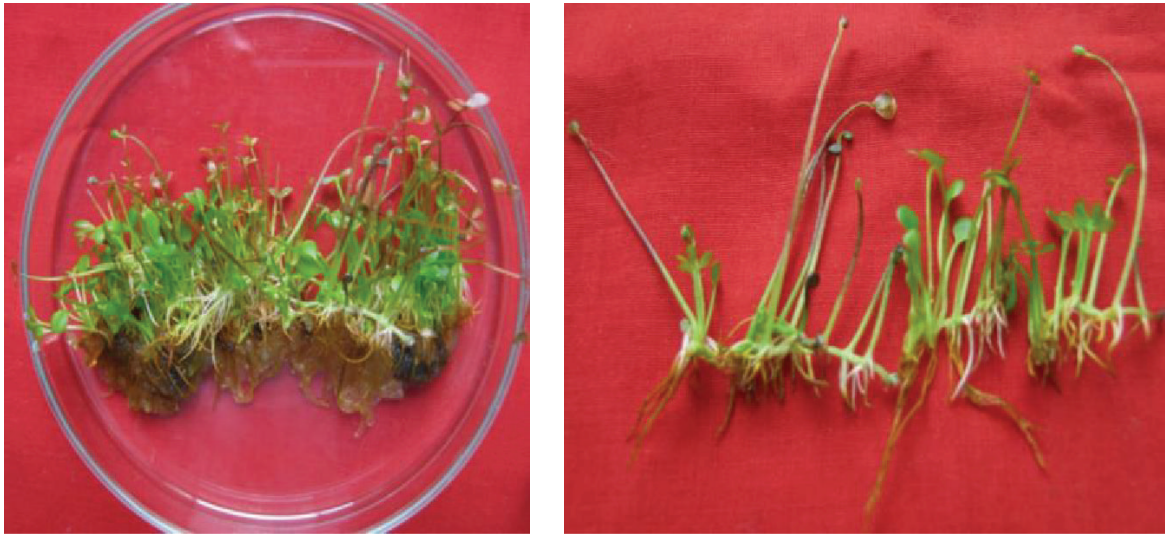

(e)

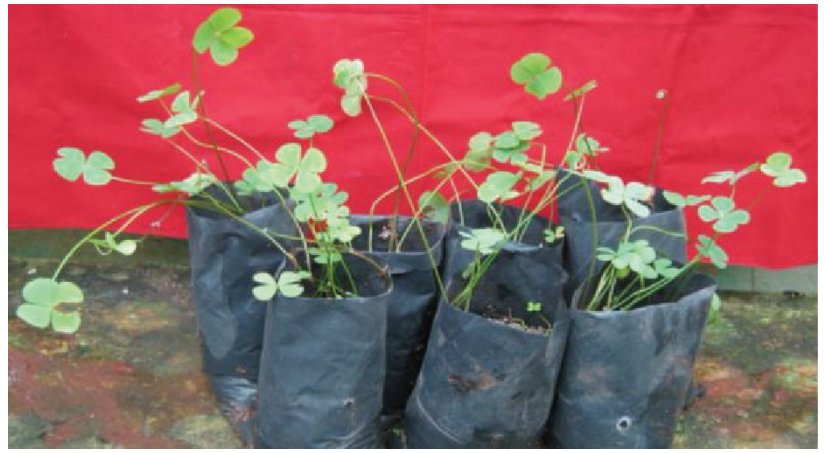

(g)

FIGURE 1: (a) Regeneration of leaflets from the rhizome explants on MS medium. (b) Early stage of multiplication (stunted growth of fronds). (c) Development of multiple sporophytes on half strength MS medium without growth hormones. (d and e) In vitro propagated sporophytes with fronds and roots. (f) Hardening of sporophytes of M. quadrifolia in soilrite. (g) Hardened sporophytes growing in the fern house.

Knop's nutrient solution and half strength MS medium by various researchers $[28,40]$.

3.3. In Vitro Rhizogenesis. Roots induction was observed after 4th subculture of sporophytic shoots on hormone-free half strength MS medium. The shoots were separated and transferred to the half strength MS medium, where number of shoots with thin and long creeping rhizomes was increased quantitatively in clusters. Best rooting frequency $(100 \%)$ was achieved on hormone-free half strength MS medium (Figures $1(\mathrm{~d})$ and $1(\mathrm{e}))$. The present results were also supported by Rolli et al. [39] and reported development of complete sporophytes on hormone-free medium. Banciu et al. [28] reported rooted sporophytes in Knop's liquid medium. Generally, auxins are used in rooting of the shoots in plant tissue culture experiments [41, 42] but in case of $M$. quadrifolia good rooting was reported without augmentation of any growth regulator with the MS medium. Breznovits and Mohay [43] also maintained Marsilea sporophytes on hormone-free half strength MS medium. Ravi et al. [36] grown spores derived gametophytes on half strength MS medium also support our results. 
3.4. Hardening and Acclimatization of In Vitro Grown Sporophytes. The in vitro regenerated plantlets were acclimatized for conservative expression in different environmental conditions. The plantlets were taken out from the culture vessels and the traces of agar were removed using soft brush to avoid damage of the roots. Care has been taken while removing the agar, since the sporophytic roots were very soft and delicate. The plantlets were initially shifted to sterile soilrite containing paper cups (Figure 1(f)) and covered with transparent membrane and placed in the fern house to maintain high humidity. This setup was moistened after every three days to maintain semiaquatic environment for four weeks. Once the roots were adapted to external environmental conditions, these were shifted to nursery polybags, which contain clay and garden soil. Addition of clay with garden soil created semiaquatic environment, since, it has water holding capacity for long time. Rolli et al. [39] acclimatized plantlets by culturing on hormone-free MS medium and $2 \mathrm{iP}$ containing medium. It was reported that the hardened plants failed to survive in soil mixtures devoid of clay. The hardened plantlets produced new sporophytic shoots from their rhizomes (Figure $1(\mathrm{~g})$ ). The plantlets hardened were morphologically identical with the native plants in external features. About $92 \%$ of plantlets survived under the field conditions in present study.

3.5. Conclusion. An efficient micropropagation protocol has been developed for a threatened and economically important fern, M. quadrifolia. The aseptic cultures were raised at the morphogenic level of axillary shoots, multiple shoots, and rooted plantlets from the small portion of rhizome tissues. The developed plantlets can be reintroduced in the natural habitat or preserved in cells or tissue culture laboratories for future studies.

\section{Disclosure}

The present research work has not involved any human participants and/or animal.

\section{Conflict of Interests}

The authors report that there is no conflict of interests regarding the publication of this paper.

\section{Acknowledgment}

The authors are grateful to the Department of Science, Technology and Environment, Government of Puducherry, for providing financial support as grant-in-aid scheme.

\section{References}

[1] J. G. Pausas and L. Sáez, "Pteridophyte richness in the NE Iberian Peninsula: biogeographic patterns," Plant Ecology, vol. 148, no. 2, pp. 195-205, 2000.

[2] B. E. Serviss and J. H. Peck, "New and noteworthy records of several non-native vascular plant species in Arkansas," Journal of the Botanical Research Institute of Texas, vol. 2, no. 1, pp. 637641, 2008.

[3] F. Bonafede, D. Dallai, C. Del Prete, and L. Maffettone, "Marsilea quadrifolia L. in Emilia Romagna province, Italy: geographical distribution, ecology and integrated in and ex situ conservation issues," Atti della Societa dei Naturalisti e Matematici di Modena, vol. 133, pp. 183-211, 2002.

[4] W.-Y. Kao and B.-L. Lin, "Phototropic leaf movements and photosynthetic performance in an amphibious fern, Marsilea quadrifolia," Journal of Plant Research, vol. 123, no. 5, pp. 645653, 2010.

[5] P. Soni and L. Singh, "Marsilea quadrifolia L.-a valuable culinary and remedial fern in Jaduguda, Jharkhand, India," International Journal of Life Sciences and Pharma Research, vol. 2, pp. 99-104, 2012.

[6] J. R. Snape, S. J. Maund, D. B. Pickford, and T. H. Hutchinson, "Ecotoxicogenomics: the challenge of integrating genomics into aquatic and terrestrial ecotoxicology," Aquatic Toxicology, vol. 67, no. 2, pp. 143-154, 2004.

[7] A. Ahmad, R. Ghufran, and A. W. Zularisam, "Phytosequestration of metals in selected plants growing on a contaminated Okhla Industrial Areas, Okhla, New Delhi, India," Water, Air, and Soil Pollution, vol. 217, no. 1-4, pp. 255-266, 2011.

[8] T. G. Gini and G. J. Jothi, "Preliminary phytochemical screening of whole plant extracts of Peperomia pellucida (Linn.) HBK (Piperaceae) and Marsilea quadrifolia Linn. (Marsileaceae)," International Journal of Pharmacognosy and Phytochemical Research, vol. 5, no. 3, pp. 200-214, 2013.

[9] J. J. Schofield, Discovering Wild Plants: Alaska, Western Canada, the Northwest, Alaska Northwest Books, GTE Discovery Publications, Bothell, Wash, USA, 1989.

[10] J. H. Kim, H.-T. Cho, and H. Kende, " $\alpha$-expansins in the semiaquatic ferns Marsilea quadrifolia and Regnellidium diphyllum: evolutionary aspects and physiological role in rachis elongation," Planta, vol. 212, no. 1, pp. 85-92, 2000.

[11] A. Snehunsu, N. Mukunda, M. C. S. Satish Kumar et al., "Evaluation of anti-epileptic property of Marsilea quadrifolia Linn. in maximal electroshock and pentylenetetrazole-induced rat models of epilepsy," Brain Injury, vol. 27, no. 13-14, pp. 1707$1714,2013$.

[12] T. Thirunarayanan and S. Rajkumar, "Ethnobotanical survey regarding the management of liver disorders by traditional healers of Vellore district, Tamil Nadu, India," International Journal of Pharmacology and Clinical Sciences, vol. 1, no. 2, pp. 24-31, 2012.

[13] V. S. Ramachandran, "Wild edible plants of the Anamalais, Coimbatore district, Western Ghats, Tamil Nadu," Indian Journal of Traditional Knowledge, vol. 6, pp. 173-176, 2007.

[14] P. Anastasiu, G. Negrean, C. Basnou, and C. Sirbu, "A preliminary study on the neophytes," in Biological InvasionsFrom Ecology to Conservation, W. Rabitsch, F. Essl, and F. Klingenstein, Eds., pp. 181-192, NEOBIOTA, 2007.

[15] A. K. Gupta, “Marsilea quadrifolia," IUCN Red List of Threatened Species, 2011. Version 2011.2., http://www.iucnredlist.org/.

[16] R. V. Lansdown, "Marsilea quadrifolia," The IUCN Red List of Threatened Species, 2013; Version 2015.1, June 2015, http://www iucnredlist.org/.

[17] B. E. Schneider, "The four leaf water clover (Marsilea quadrifolia L.)-an endangered species. Aspects of conservation and management," Transylvanian Review of Systematical and Ecological Research, vol. 16, p. 165, 2014. 
[18] World Conservation Monitoring Centre, "Checklists for the CORINE Biotopes Programme and its application in the PHARE countries of Central and East Europe: including comparisons with relevant conventions and agreements on the conservation of European species and habitats," 1994, http://www.archive.org/details/checklistsforcor94wcmc.

[19] E. Estrelles, A. M. Ibars, J. Iranzo, and F. Morales, "Recuperation and reintroduction of Marsilea quadrifolia in the rice fields of Ebro's Delta (Tarragona, Spain)," Botanica Complutensis, vol. 25, pp. 251-259, 2001.

[20] D. Strat, "Marsilea quadrifolia L. in the protected wetlands from Romania," in Proceedings of the International Conference on Water Resources and Wetlands, P. Gâştescu, W. Lewis Jr., and P. Breţcan, Eds., pp. 449-457, Transversal Publishing House, Tulcea, Romania, September 2012.

[21] S. K. Bharati, D. C. Manabendra, and M. P. Behari, "In vitro propagation in pteridophytes: a review," International Journal of Research in Ayurveda and Pharmacy, vol. 4, no. 2, pp. 297-303, 2013.

[22] D. Dallai, C. Del Prete, E. Sgarbi, and M. Grimaudo, "Integrated in situ/ex situ plant conservation practices managed by University Botanic Garden of Modena," Bollettino dei Musei e Degli Istituti Biologici dell'Università di Genova, vol. 72, pp. 33-42, 2010.

[23] M. Bonaiuti, From Bioeconomics to Degrowth: GeorgescuRoegen's 'New Economics' in Eight Essays, Taylor \& Francis, 2011.

[24] D. Cachita-Cosma, "Metode in vitro la plantele de cultura-naze teoretice si practice," in Edit Ceres, Bucuresti, pp. 182-225, 1987.

[25] H. Fernández and M. A. Revilla, "In vitro culture of ornamental ferns," Plant Cell, Tissue and Organ Culture, vol. 73, no. 1, pp. $1-13,2003$.

[26] S. Khan, M. Raziq, and H. A. Kayani, "In vitro propagation of bird's nest fern (Asplenium nidus) from spores," Pakistan Journal of Botany, vol. 40, no. 1, pp. 91-97, 2008.

[27] E. Rolli, S. Pizzoni, and A. Ricci, "Multiplication of Marsilea quadrifolia L. by micropropagation," Italus Hortus, vol. 16, pp. 147-150, 2009.

[28] C. Banciu, M. E. Carasan, and A. Brezeanu, "In vitro propagation of the endangered species Marsilea quadrifolia L.morphological and biochemical analysis of the regenerates," Romanian Biotechnological Letters, vol. 14, no. 1, pp. 4139-4145, 2009.

[29] T. Murashige and F. Skoog, "A revised medium for rapid growth and bioassays with tobacco tissue cultures," Physiologia Plantarum, vol. 15, no. 3, pp. 473-497, 1962.

[30] D. W. S. Mok and M. C. Mok, "Cytokinin metabolism and action," Annual Review of Plant Physiology and Plant Molecular Biology, vol. 52, pp. 89-118, 2001.

[31] T. Werner and T. Schmülling, "Cytokinin action in plant development," Current Opinion in Plant Biology, vol. 12, no. 5, pp. 527-538, 2009.

[32] M. Nakamura and M. Maeda, "Isolation and culture of protoplasts from young sporophytes of Salvinia natans aseptically obtained by co-culture of female and male gametophytes," Plant Cell, Tissue and Organ Culture, vol. 36, no. 2, pp. 237-242, 1994.

[33] H. Fernández, A. M. Bertrand, and R. Sánchez-Tamés, "Biological and nutritional aspects involved in fern multiplication," Plant Cell, Tissue and Organ Culture, vol. 56, no. 3, pp. 211-214, 1999.

[34] A. Kuriyama and M. Maeda, "Direct production of sporophytic plants from spores of Equisetum arvense," Plant Cell, Tissue and Organ Culture, vol. 58, no. 1, pp. 77-79, 1999.
[35] H. K. Cheema, "Multiple bud formation and plant regeneration in aquatic fern in vitro," Plant Biotechnology, vol. 89, pp. 173-177, 2005.

[36] B. X. Ravi, G. V. A. Varuvel, R. kilimas, and J. Robert, "Apogamous sporophyte development through spore reproduction of a South Asia's critically endangered fern: Pteris tripartita Sw." Asian Pacific Journal of Reproduction, vol. 4, no. 2, pp. 135-139, 2015.

[37] B. L. Liu, "Abscisic acid induces land form characteristics in Marsilea quadrifolia L.," American Journal of Botany, vol. 71, no. 5, pp. 638-644, 1984.

[38] B.-L. Lin and W.-J. Yang, "Blue light and abscisic acid independently induce heterophyllous switch in Marsilea quadrifolia," Plant Physiology, vol. 119, no. 2, pp. 429-434, 1999.

[39] E. Rolli, F. Brunoni, M. Marieschi, A. Torelli, and A. Ricci, "In vitro micropropagation of the aquatic fern Marsilea quadrifolia L. and genetic stability assessment by RAPD markers," Plant Biosystems, vol. 149, no. 1, pp. 7-14, 2015.

[40] A. Brezeanu and C. Banciu, "Comparative studies regarding ultra structure of Marsilea quadrifolia (Pteridophyte) leaf mesophyll cells in vivo and in vitro culture," Romanian Journal of Biology-Plant Biology, vol. 54, pp. 13-24, 2009.

[41] M. S. Shekhawat, N. Kannan, M. Manokari, and M. P. Ramanujam, "En efficient micropropagation protocol for highfrequency plantlet regeneration from liquid culture of nodal tissues in a medicinal plant Turnera ulmifolia L.," Journal of Sustainable Forestry, vol. 33, no. 4, pp. 327-336, 2014.

[42] M. S. Shekhawat, N. Kannan, M. Manokari, and C. P. Ravindran, "Enhanced micropropagation protocol of Morinda citrifolia L. through nodal explants," Journal of Applied Research on Medicinal and Aromatic Plants, 2015.

[43] A. Breznovits and J. Mohay, "In vitro problems related to the propagation of different fern species, symposium on in vitro problems related to mass propagation of horticultural plants," Acta Horticulturae, vol. 212, pp. 427-432, 1987. 

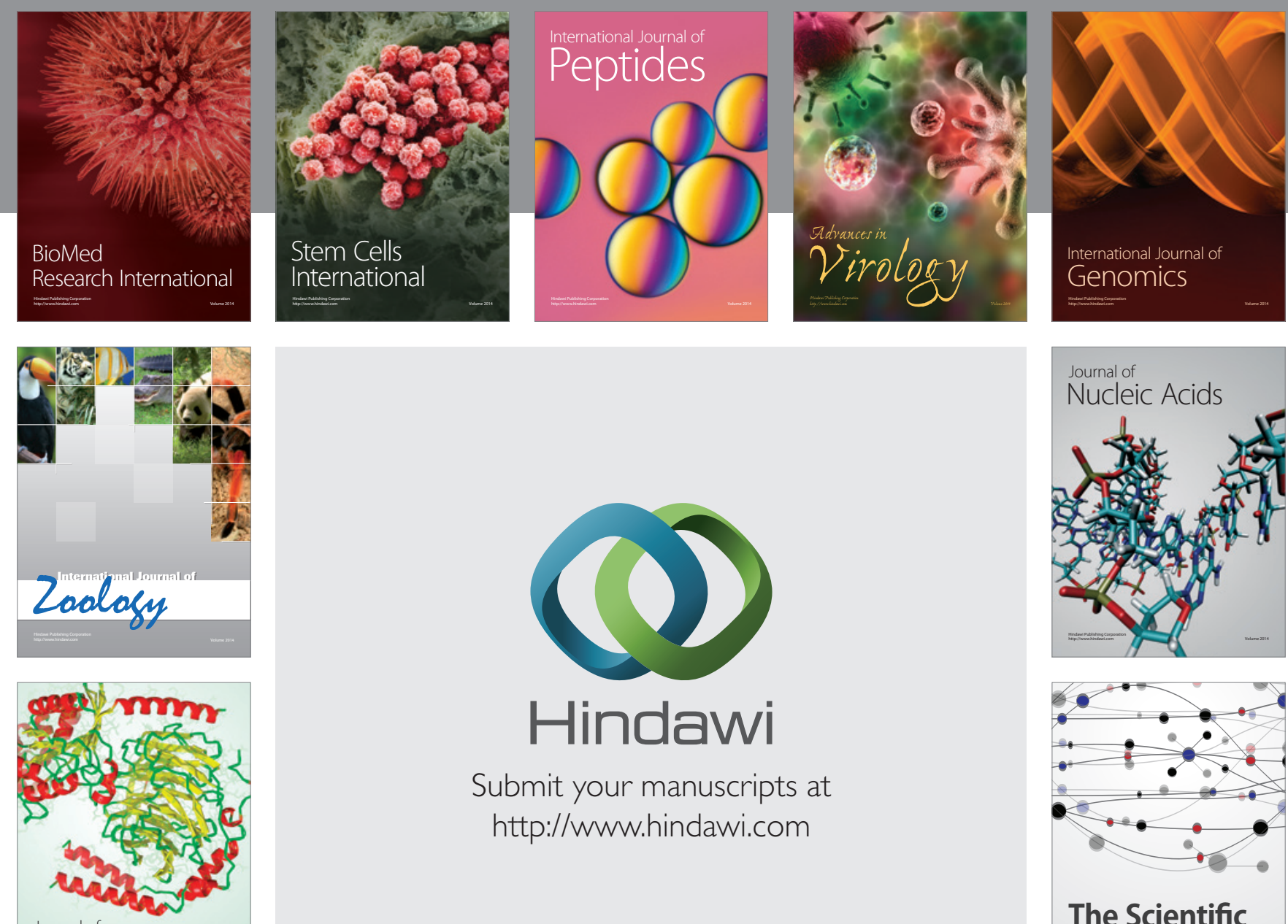

Submit your manuscripts at

http://www.hindawi.com

Journal of
Signal Transduction
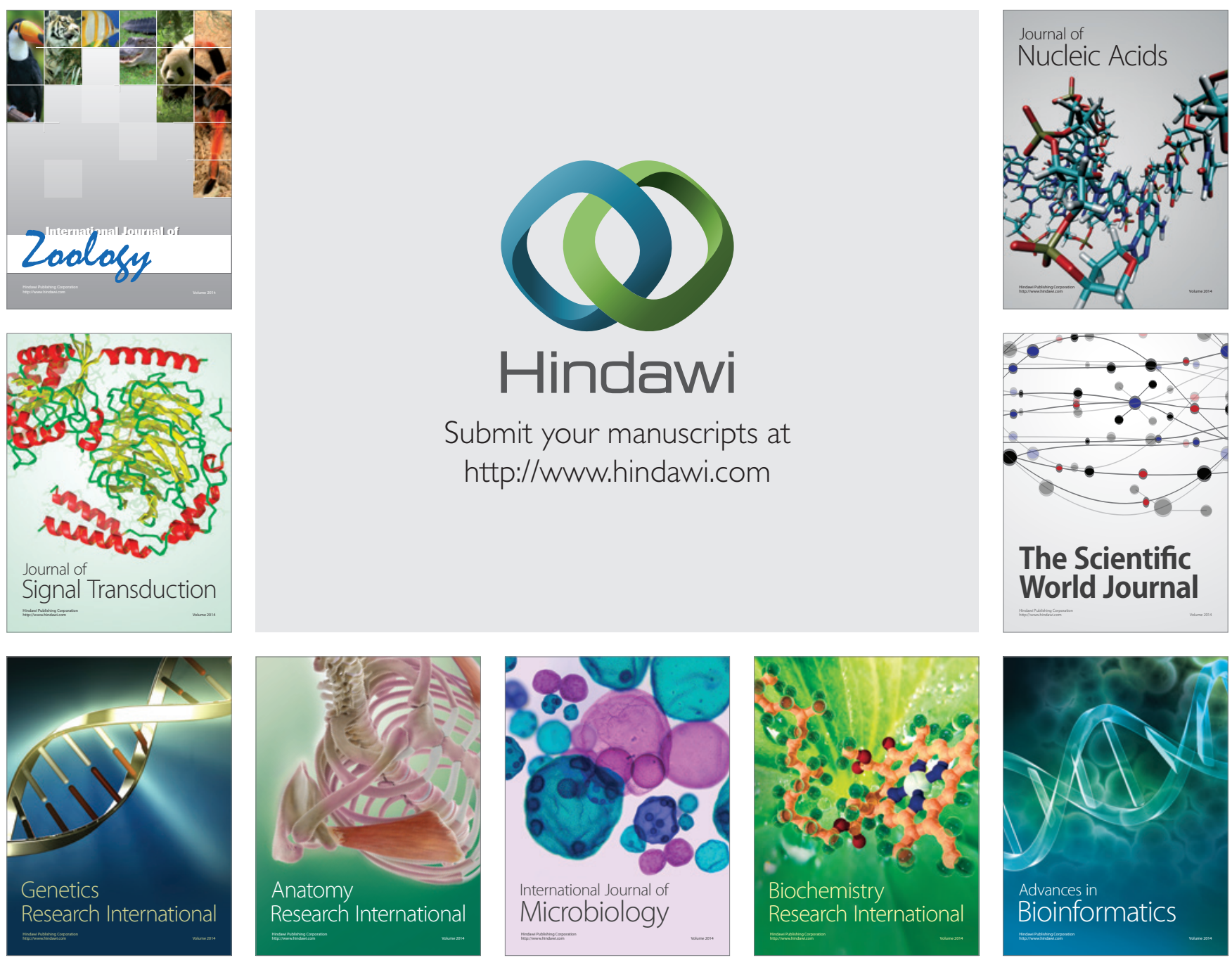

The Scientific World Journal
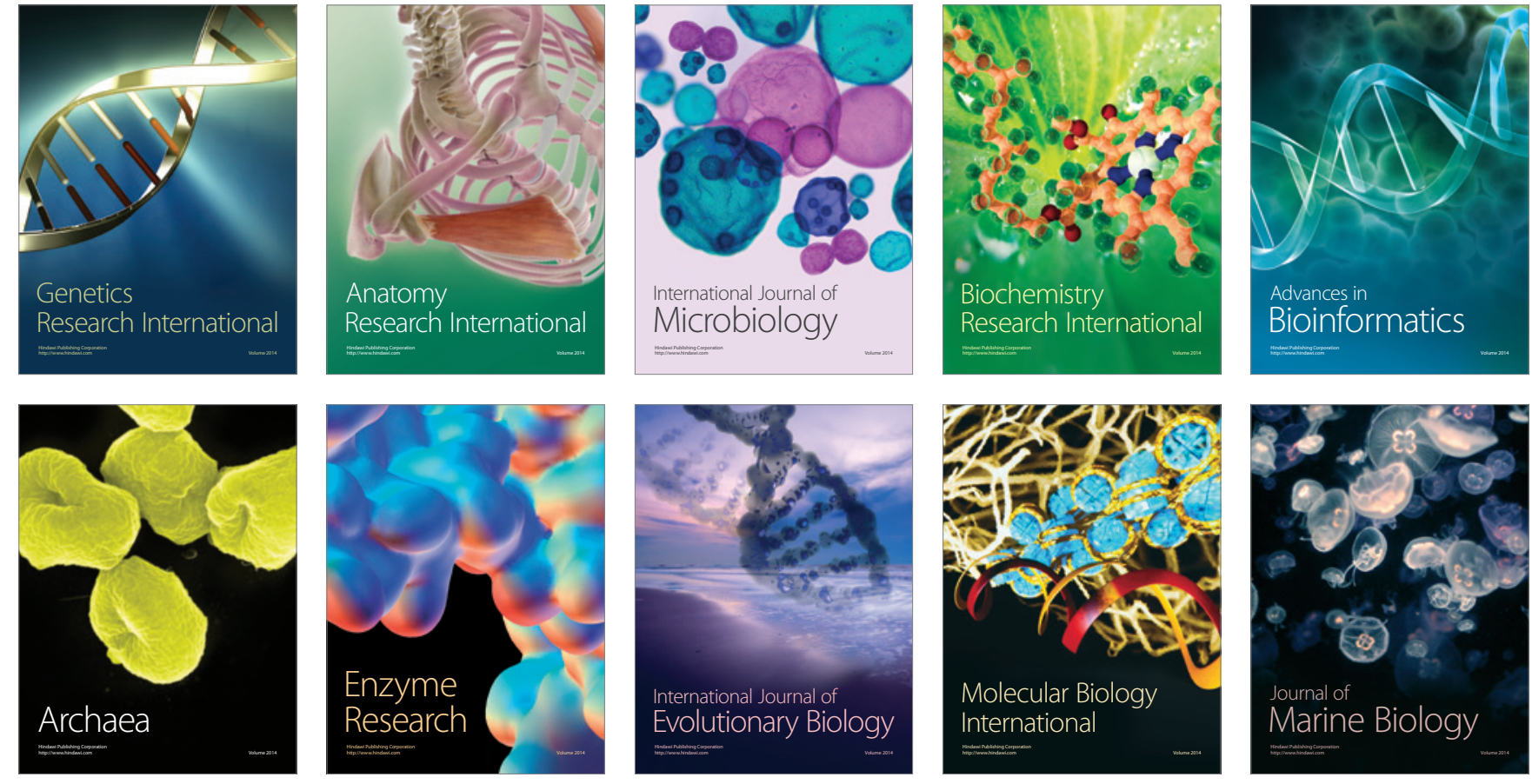